THE POLITICS OF WHITENESS 
POLITICS AND SOCIETY IN TWENTIETH-CENTURY AMERICA SERIES EDITORS William Chafe, Gary Gerstle, and Linda Gordon A list of titles in this series appears at the back of the book 


\section{THE POLITICS OF WHITENESS}

RACE, WORKERS, AND CULTURE

IN THE MODERN SOUTH

Michelle Brattain

PRINCETON UNIVERSITY PRESS PRINCETON AND OXFORD 


\section{Copyright $(C 2001$ by Princeton University Press}

Published by Princeton University Press, 41 William Street, Princeton, New Jersey 08540

In the United Kingdom: Princeton University Press, 3 Market Place, Woodstock, Oxfordshire OX20 1SY

All Rights Reserved

Chapter 6 appeared in a somewhat different form as "Making Friends and Enemies: Textile Workers and Politics in Post-World War II Georgia," Joumal of Southern History 63 (February 1997): 91-138. It appears here by permission of the publisher.

\section{Library of Congress Cataloging-in-Publication Data}

\section{Brattain, Michelle, 1968-}

The politics of whiteness : race, workers, and the culture in the modern South / Michelle Brattain.

p. cm.-(politics and society in twentieth-century America) Includes bibliographical references and index.

ISBN 0-691-00731-4 (alk. paper)

1. Labor-Southern States-History. 2. Afro-Americans-

Employment-Southern States-History. 3. Labor movementSouthern States-History. 4. Southern States-Race relationsHistory. I. Title. II. Series.

HD8072.5 B727 2001

$331^{\prime} .0975-\mathrm{dc} 21 \quad 00-045272$

This book has been composed in Sabon

The paper used in this publication meets the minimum requirements of ANSI/NISO Z39.48-1992 (R1997)

(Permanence of Paper)

www.pup.princeton.edu

Printed in the United States of America

$\begin{array}{llllllllll}10 & 9 & 8 & 7 & 6 & 5 & 4 & 3 & 2 & 1\end{array}$ 
For Andrew 
